\title{
Analysis of possible impacts of climate change on the hydrological regimes of different regions in Germany
}

\author{
H. Bormann \\ University of Oldenburg, Department of Biology and Environmental Sciences, Oldenburg, Germany \\ Received: 19 December 2008 - Revised: 5 March 2009 - Accepted: 28 April 2009 - Published: 10 August 2009
}

\begin{abstract}
In this study, the impact of climate change scenarios on the hydrological regimes of five different regions in Germany is investigated. These regions (Northwest Germany, Northeast Germany and East German basins, upper and lower Rhine, pre-Alps) differ with respect to present climate and projected climate change. The physically based SVAT-model SIMULAT is applied to theoretical soil columns based on combinations of land use, soil texture and groundwater depth to quantify climate change effects on the hydrological regime. Observed climate, measured at climate stations of the German Weather Service (1991-2007), is used for comparison with climate projections (2071-2100) generated by the regional scale climate model WETTREG.

While all climate scenarios implicate an increase in precipitation in winter, a decrease in precipitation in summer and an increase in temperature, the simulated impacts on the hydrological regime are regionally different. In the Rhine region and in Northwest Germany, an increase in the annual runoff and groundwater recharge is simulated despite the increase in temperature and potential evapotranspiration. In the Eastern part of Germany and the pre-Alps, annual runoff and groundwater recharge will decrease. Due to dry conditions in summer, the soil moisture deficit will increase (in Northeast Germany and the East German basins in particular) or remain constant (Rhine region). In all regions the seasonal variability in runoff and soil moisture status will increase. Despite regional warming actual evapotranspiration will decrease in most regions except in areas with shallow groundwater tables and the lower Rhine. Although the study is limited by the fact that only one climate model was used to drive one hydrologic model, the study shows that the hydrological regime will be
\end{abstract}

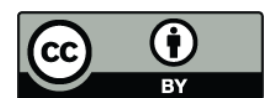

Correspondence to: $\mathrm{H}$. Bormann (helge.bormann@uni-oldenburg.de) affected by climate change. The direction of the expected changes seems to be obvious as well as the necessity of the adaptation of future water management strategies.

\section{Introduction}

Studies on global and regional climate change of the past century have revealed that during the last 50 years the global and regional climate has changed faster than before in history (IPCC, 2007; Schönwiese, 1999). Climate change mostly is attributed to a change in temperature firstly, but in addition to changes in temperature these studies in particular report on changes in precipitation. At the same time, changes in the runoff regimes of German river catchments have already been identified for the last decades which mainly can be attributed to climate change impacts (Bormann, 2009; Belz et al., 2007; Wechsung et al., 2006).

From global and regional climate simulations summarised in the actual climate changes assessment report (IPCC, 2007) as well as in national reports (e.g. UBA, 2007) it can be expected that climate change will affect the hydrological cycle in many regions of the world. The hydrological changes, mainly driven by changes in precipitation amounts and patterns and temperature, will affect surface as well as groundwater and other components of the hydrological cycle such as soil moisture and evapotranspiration. Based on the coherences deduced by the IPCC it can be assumed that the average hydrological behaviour of catchments and regions may change as well as the reaction to extreme events.

In comparison to good data availability on surface water data which can be analysed towards climate induced trends, long-term data on groundwater, soil moisture status and evapotranspiration are not available. Therefore, hydrological

Published by Copernicus Publications on behalf of the European Geosciences Union. 
simulation models are often used to translate climate change projections into hydrological projections. For good reasons several authors questioned the ability of models to represent the effects of a changing environment on the hydrological cycle (e.g. Wagener, 2007). Jiang et al. (2007) showed that the model specific sensitivity to climate change may differ significantly between different hydrological catchment models. But the question arises which alternatives to such model application exist to quantify climate changes impacts on the hydrological cycle. Process based models might be the solution required: models, which are validated for different climates and which have been proven to be able to represent the hydrological processes without any parameter calibration.

In the last years, many hydrological impact studies have been presented which were based on regionalised climate scenarios driving hydrological models (e.g. Fowler et al., 2007; Kilsby et al., 2007; Thodsen, 2007; Wilby et al., 2006). Most of those studies aimed at the representation of the climate change impact on river discharge. Regional studies focusing on seasonal changes in the whole hydrological regime, including soil moisture status, groundwater recharge and evapotranspiration, nevertheless remained scarce.

In this study, the physically based soil-vegetationatmosphere-transfer (SVAT) model SIMULAT is applied to quantify the effect of climate on regional hydrological regimes. Based on freely available observed climate data (German Weather Service) and climate scenarios of the regional climate model WETTREG, the change in regional hydrological regimes is assessed for five different regions in Germany. Results of daily water balance simulations are aggregated to monthly values in order to represent regionally different and typical seasonal variations (= hydrological regimes) in the investigated components of the water cycle. Possible future changes in those typical hydrological regimes are discussed in this paper.

\section{Material and methods}

\subsection{Hydrological simulation model}

The SIMULAT model (Diekkrüger and Arning, 1995; Bormann, 2001) is used in this study to calculate water flows and water balances for typical catchment properties of the five investigated regions. SIMULAT is a physically based and one dimensional SVAT scheme and is based on the following process descriptions:

- Potential evapotranspiration is calculated by the Penman-Monteith method. In order to compute the actual evapotranspiration, potential evapotranspiration is reduced by a function taking the actual soil moisture status (Feddes et al., 1978) and the number of days after the last rainfall (Ritchie, 1972) into account.
- Infiltration is determined using a semi-analytical solution of the Richards' equation according to Smith and Parlange (1978).

- Soil water flow is calculated by a numerical solution of the Richards' equation using finite differences.

- The calculation of the snow melt is based on the degree day method, while snow accumulation is assumed for temperatures below $0^{\circ} \mathrm{C}$.

- Interflow is computed by Darcy's law in case of saturated computational soil layers. Lateral outflow from this computational unit is then determined by lateral hydraulic conductivity and inclination.

SIMULAT has been validated by several studies at different spatial scales from plot-scale to meso-scale (Diekkrüger and Arning, 1995; Kuhn, 1998; Bormann et al., 1999; Aden and Diekkrüger, 2000; Stephan, 2003; Bormann et al., 2005; Giertz et al., 2006) and for different climatic regions (Western and Central Europe, West Africa). Within all these studies, a parameter calibration was not performed except for a linear storage based groundwater reservoir used for regional scale model applications. All other parameters (soil and plant parameters in particular) were derived from local scale measurements and from literature (e.g., Richter et al., 1996). For small scale applications, the simulation quality without any parameter calibration was comparable to the quality of other calibrated site models (Diekkrüger et al., 1995).

\subsection{Typical regional properties}

In order to reduce demand on input data and calculation time, instead of catchment data sets on soil and land use a combination of theoretical soil columns and standard land use parameter sets is used. Theoretical soil columns are introduced to describe the water retention curve and the unsaturated conductivity curve of all texture classes according to the German texture classification (Ad-hoc AG Boden, 2005). The pedotransfer function according to Rawls and Brakensiek (1985) is applied to the centre of gravity of each soil texture class. According to the German soil texture classification the soil texture triangle is divided into 31 texture classes: seven clay classes, ten loam classes, seven silt classes and seven sand classes.

For each texture class, simulations are performed considering three different land uses (mixed forest, grassland, and agriculture), two different groundwater depths (no groundwater interaction versus shallow groundwater table) and the regional climates, represented by observed data and scenarios of three climate stations for each of the five investigated regions: Northwest Germany, Northeast Germany and East German basins, upper Rhine, lower Rhine and pre-alpine region. Defining the groundwater interaction, two different lower boundary conditions are selected consisting of "free 
Table 1. Regional climate change between present time and the period 2071-2100, projected by the WETTREG model.

\begin{tabular}{lllll}
\hline $\begin{array}{l}\text { Region } \\
\text { (climate stations) }\end{array}$ & Scenario & Temperature & $\begin{array}{l}\text { Summer } \\
\text { precipitation }\end{array}$ & $\begin{array}{l}\text { Winter } \\
\text { precipitation }\end{array}$ \\
\hline $\begin{array}{l}\text { Northwest Germany } \\
\text { (Bremen, Hamburg, Schleswig) }\end{array}$ & $\mathrm{A} 1 \mathrm{~B}$ & $+2.5^{\circ} \mathrm{C}$ & $-20 \%$ & $+25 \%$ \\
Northeast Germany and East & $\mathrm{A} 1 \mathrm{~B}$ & $+2.0^{\circ} \mathrm{C}$ & $-10 \%$ & $+15 \%$ \\
German basins & $\mathrm{B} 1$ & $+2.5^{\circ} \mathrm{C}$ & $-50 \%$ & $+20 \%$ \\
(Leipzig, Magdeburg, Potsdam) & & $+2.0^{\circ} \mathrm{C}$ & $-30 \%$ & $+10 \%$ \\
Lower Rhine region & $\mathrm{A} 1 \mathrm{~B}$ & $+2.3^{\circ} \mathrm{C}$ & $-10 \%$ & $+50 \%$ \\
(Düsseldorf, Münster) & $\mathrm{B} 1$ & $+1.8^{\circ} \mathrm{C}$ & $-5 \%$ & $+30 \%$ \\
Upper Rhine region & $\mathrm{A} 1 \mathrm{~B}$ & $+2.3^{\circ} \mathrm{C}$ & $-20 \%$ & $+40 \%$ \\
(Frankfurt, Karlsruhe) & $\mathrm{B} 1$ & $+1.5^{\circ} \mathrm{C}$ & $-20 \%$ & $+20 \%$ \\
Pre-alpine region & $\mathrm{A} 1 \mathrm{~B}$ & $+2.25^{\circ} \mathrm{C}$ & $-25 \%$ & $+35 \%$ \\
(Augsburg, Kempten, München) & $\mathrm{B} 1$ & $+1.85^{\circ} \mathrm{C}$ & $-15 \%$ & $+20 \%$ \\
\hline
\end{tabular}

drainage" (=no interaction with groundwater) and a fixed groundwater table of $3 \mathrm{~m}$ (= shallow groundwater).

\subsection{Climate data and climate scenarios}

In order to be able to assess the impact of climate change on the hydrological regime, SIMULAT is driven by different climate data sets. Current climate is represented by observed climate data from the German Weather Service (DWD). Freely available data from DWD website (www.dwd.de) cover a time period of 1991-2008. A correction of observed as well as simulated precipitation data (see below) was not performed.

The regional climate projections for the period 20712100 , which are used in this study, are based on the results of the WETTREG model (UBA, 2007). WETTREG is a statistical downscaling model which is based on global climate scenarios calculated by the ECHAM5 model from MPI Hamburg. WETTREG analyses the frequency of regional weather conditions based on the simulations results of the global climate model. Using this time series of regional weather conditions, meteorological time series of selected climate stations are generated considering the change in the probability of the predefined weather conditions. WETTREG generates time series of climate and precipitation stations for ten year periods up to year 2100 for three different IPCC scenarios: A1B, A2, B1. In this study, the scenarios A1B and B1 were used as model input.

The climatic changes projected by the WETTREG models were summarised to eleven regions exhibiting relatively homogenous regional changes in climate (UBA, 2007). From these regions, five regions were selected in this study: Northwest Germany, Northeast Germany and East German basins (together called "East Germany" in this paper), the upper Rhine region and the West-German lowlands (called "lower Rhine" region in this paper). The average regional climate change within these regions, projected for the time period from 2071 to 2100 is shown in Table 1. All regions are characterised by an increase in mean annual temperature and in winter precipitation. Summer precipitation is expected to decrease in all investigated regions. However, the percentages of projected change differ remarkably between the regions. Therefore, regionally different impacts of climate change on the hydrological regime are likely.

Bronstert et al. (2006) compared the suitability of different regional climate models for hydrological investigations for Southern Germany. One main result was that all downscaling methods yielded in results which represented the real conditions better then the direct output of global climate models. Statistical climate models such as WETTREG were able to represent regionally different mean conditions as well as the seasonal variability. For the calculation of groundwater recharge, all investigated models merely showed a moderate performance while WETTREG still was the best of the investigated models. Following Bronstert et al. (2006) WETTREG can be assumed to be suitable for the purpose of this study.

\section{Results: changes in the hydrological regimes}

\subsection{Changes in regional runoff regimes}

This investigation on runoff regimes is based on the simulation results of the physical based SVAT model SIMULAT. SIMULAT calculates three different runoff components (surface runoff, interflow, groundwater recharge) which are summed up for each time step to the "total runoff". In this study a daily time step is used. Daily time series of climate projections required for simulation are derived from the 20 available WETTREG realisations by determining seasonal climate change signals and superimposing these signals to the observed time series of climate. An analysis on the variability of different WETTREG realisations is not performed. 

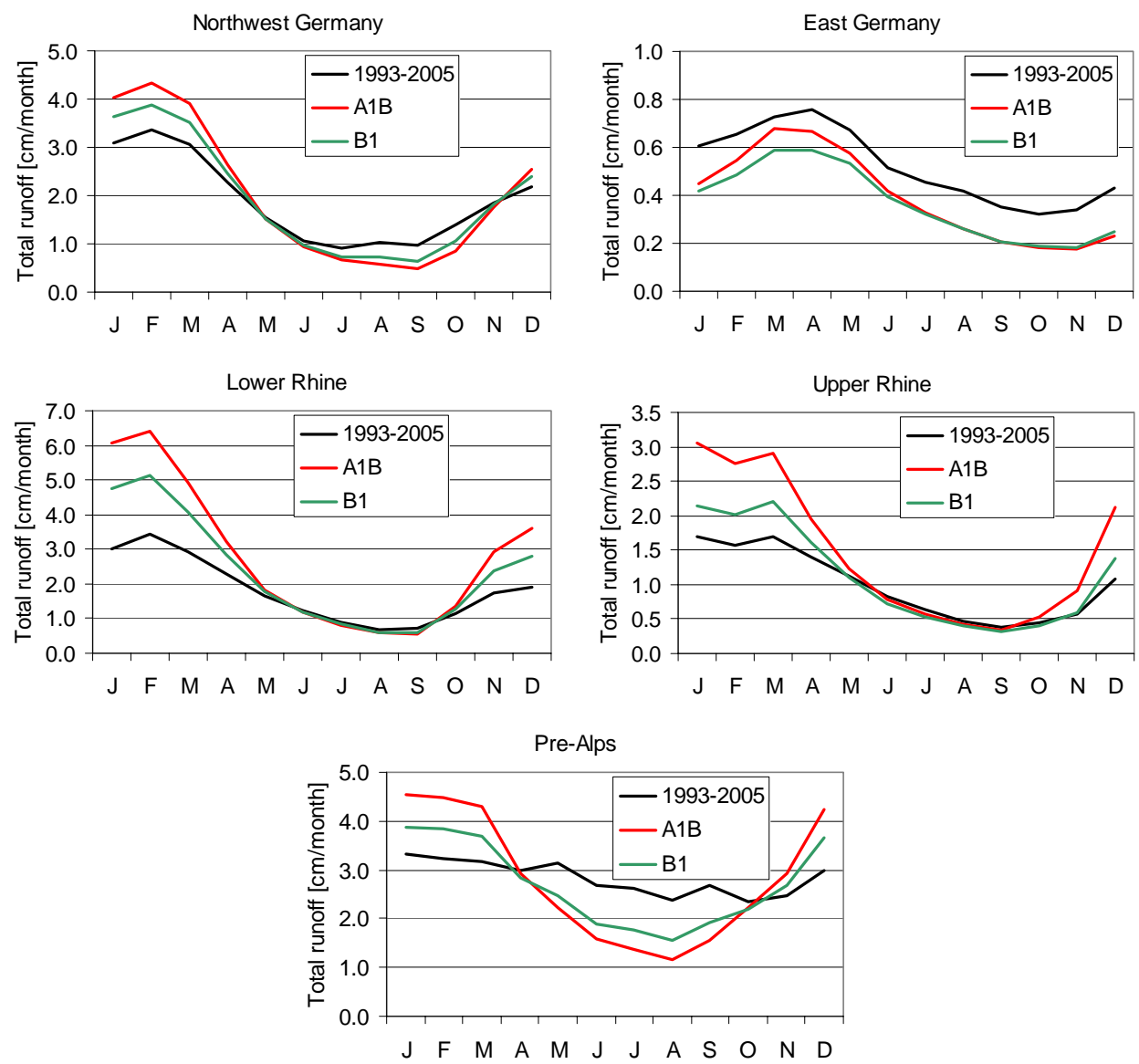

Fig. 1. Impact of climate change scenarios on the seasonal variation of simulated total runoff (= sum of surface runoff, interflow and groundwater recharge); lower boundary: free drainage.

For the analysis of the runoff regime, a further aggregation of daily simulations to mean monthly values of total runoff is performed.

Comparing the regional runoff regimes, based on measured present climate and on the WETTREG scenarios A1B and B1 for the time period 2071-2100, the simulated results are consistent with the driving regional climates. In general, a decrease in precipitation during summer time induces a decrease in runoff, and an increasing precipitation in winter leads to an increase in runoff as well (Fig. 1). One exception is East Germany where total runoff is reduced for both climate scenarios during summer and winter. The increase in evapotranspiration in winter time due to an increase in temperature overcompensates the winterly increase in precipitation. Another exception is the Rhine region where only a moderate decrease in summerly precipitation is projected by WETTREG, inducing almost no change in total runoff in the summer months. While in Northeast Germany and in the upper and lower Rhine regions the existing pluvial runoff generation regime is amplified, the runoff regime in the preAlps changes substantially: Due to the likewise important contribution of rainfall and snow melt in present time, the runoff generation regime for present time shows relatively homogenous values for all months, slightly higher in winter months compared to summer months. In future, this runoff generation regime may change significantly. Both future scenarios show the effect, that the pluvial contribution to runoff generation will be intensified while the impact of snow during winter time (snow fall, snow storage, snow melt) will be weakened due to increasing temperatures. In all investigated regions, obviously scenario A1B induces stronger changes in the runoff regime than scenario B1 does.

Compared to the seasonal variations of the total runoff, the seasonal behaviour of groundwater recharge shows the same pattern (Fig. 2). This is due to the fact that in all regions considered in this study, groundwater recharge plays a dominant role in the runoff generation process. All regions are characterised by relatively flat areas which are dominated by deep soils developed on unconsolidated sediments. Therefore, the seasonal patterns of groundwater recharge govern the seasonal dynamics of the total runoff. 

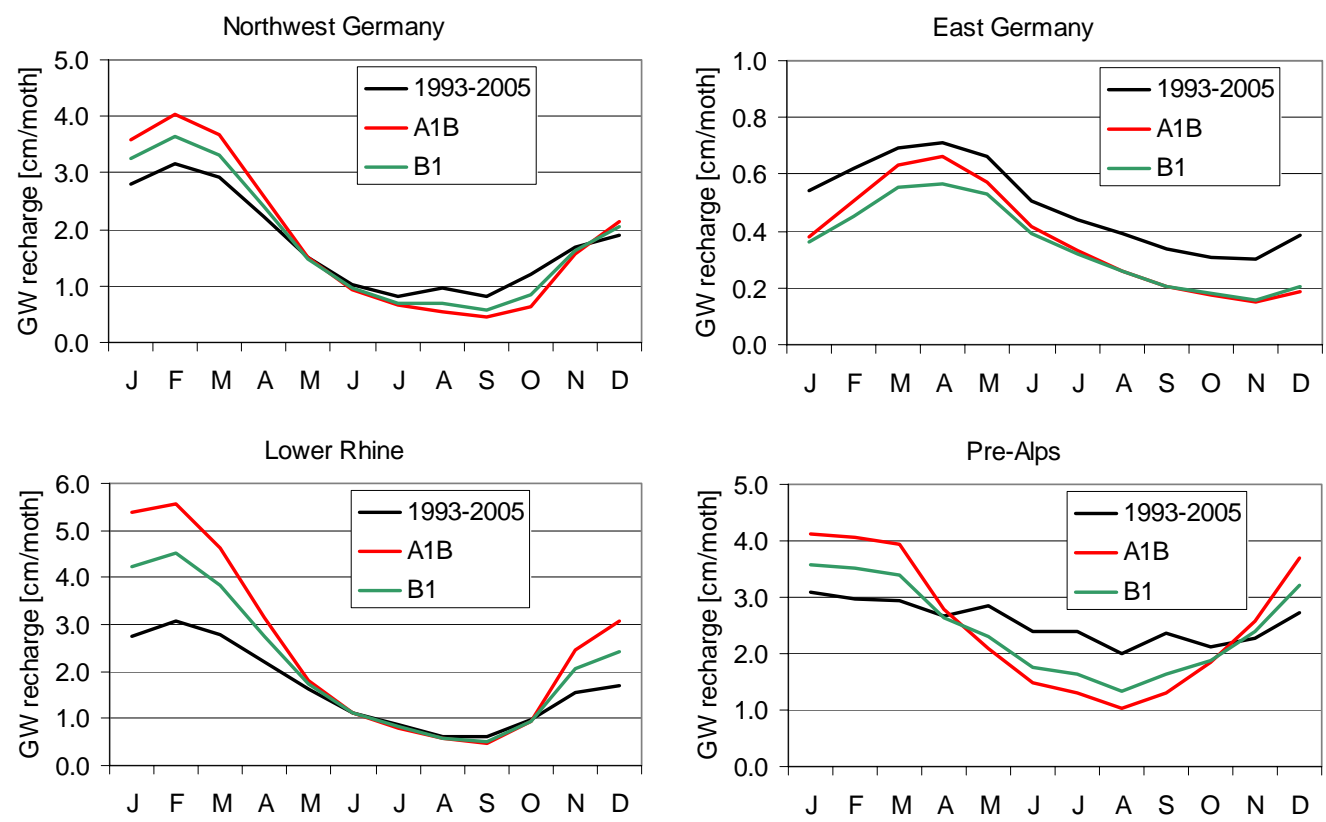

Fig. 2. Impact of climate change scenarios on the seasonal variation of simulated groundwater $(=\mathrm{GW})$ recharge; lower boundary: free drainage. Lower and upper Rhine regions show the same structure in climate change impact.

\subsection{Changes in regional evapotranspiration and soil moisture regimes}

Climate change induced changes in actual evapotranspiration (AET) are driven by changes in temperature (governing potential evapotranspiration) and changes in precipitation (governing changes in the soil moisture regime). Therefore, changes in the seasonal pattern of actual evapotranspiration are regionally variable.

Due to increased temperature and precipitation, all regions are characterised by an increased actual evapotranspiration during winter and early spring. Water can evaporate by the increased potential rate. Therefore all regions, except East Germany, show an increase in soil moisture during winter time as well. Due to the decrease in precipitation in summer, the soil moisture deficit in summer increases in all regions for both scenarios, A1B and B1. This enforced soil moisture deficit in summer overcompensates the increase in potential evapotranspiration caused by the increase in temperature, resulting in a decrease in actual evapotranspiration. However, the intensity of the change in actual evapotranspiration and the soil moisture deficit during summer differs remarkably between the WETTREG regions (Fig. 3). While in the lower and upper Rhine region the summerly decrease in evapotranspiration is small due to an only slightly intensified soil moisture deficit, the decrease in AET is larger in Northwest Germany and the pre-Alps (decrease around $10 \mathrm{~mm} / \mathrm{month}$ for scenario A1B, 5mm/month for scenario B1) and equals a decrease of about $25 \mathrm{~mm} / \mathrm{month}$ in East Germany for scenario
A1B (about $15 \mathrm{~mm} /$ month for scenario B1). These decreases in AET are accompanied with a strengthened soil moisture deficit by more than $3 \%$ by volume in the root zone for scenario $\mathrm{A} 1 \mathrm{~B}$, and more than $2 \%$ by volume for scenario B1 (Northwest Germany, East Germany, pre-Alps), while in the Rhine region the decrease in soil moisture is smaller than $1 \%$ by volume for both climate scenarios. Comparable to the runoff generation processes, scenario A1B shows for all regions in Germany intensified changes in the seasonal variability of soil moisture. With respect to actual evapotranspiration, different regions behave different depending on the precipitation amounts in summer. While in the (moist) Rhine region the maximum evapotranspiration rates increase (in the month of May; Fig. 3), maximum values of AET in the remaining regions decrease, and partly the timing of the maximum changes as well towards an earlier occurrence of the maximum (e.g., in Northwest and East Germany from June to May for both climate scenarios).

\subsection{Effects of groundwater depth, soils and land use on the patterns of change}

A comparative analysis of the effects of land use and soil properties distribution showed that the impact of land use on the change in the seasonal behaviour of the hydrological regime is small. While the effects of different land uses (e.g., forest versus grassland) and soil textures (e.g., sand versus loam) on a change in the mean annual water balances were significant (Bormann, 2008), only slight impacts on a 

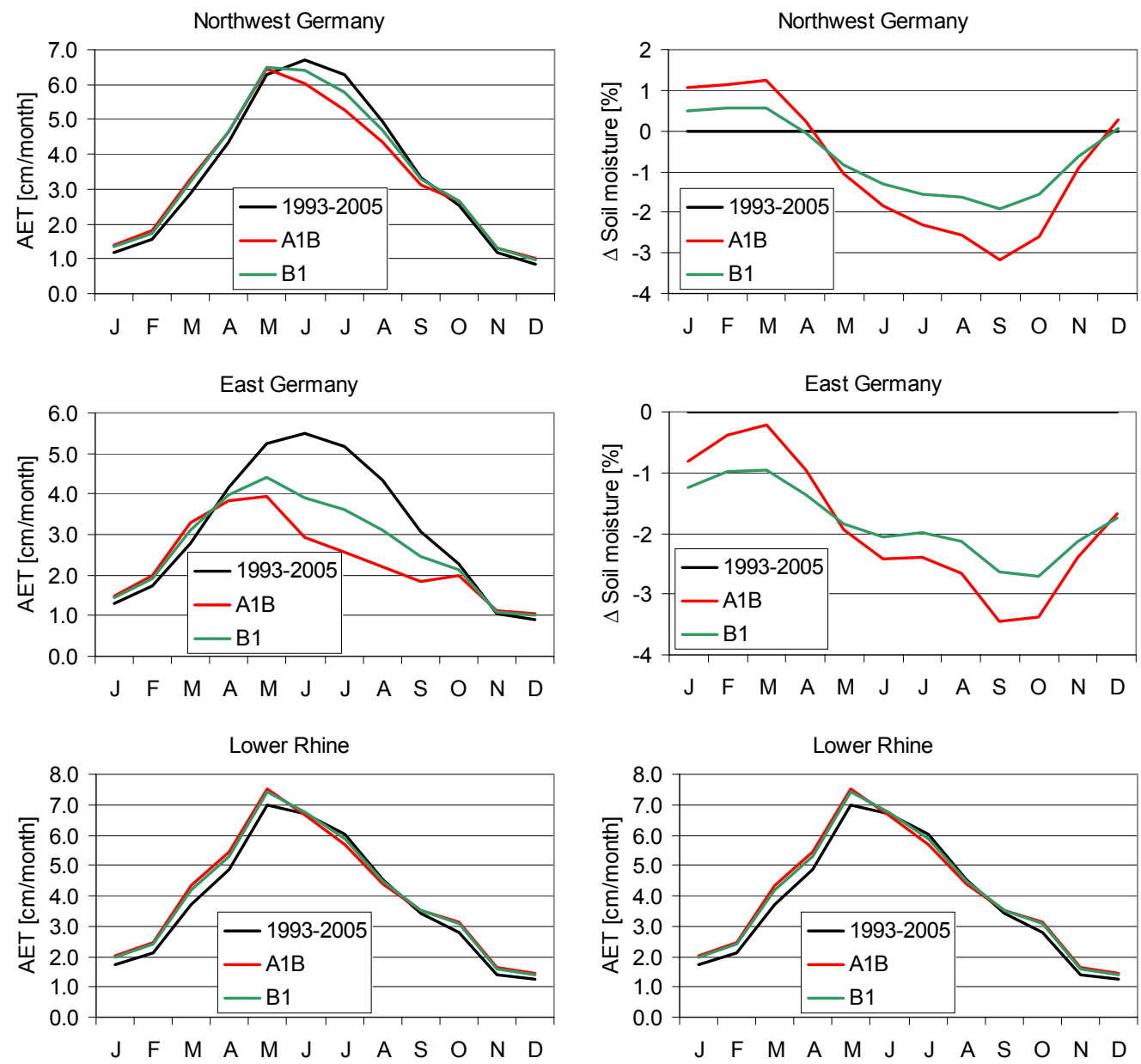

Fig. 3. Impact of climate change scenarios on the seasonal variation of simulated actual evapotranspiration (AET) and change $(\Delta)$ in soil moisture compared to present climate; lower boundary: free drainage. The sensitivity of the pre-Alps is comparable to the reaction of Northwest Germany; the sensitivity of the upper Rhine region similar to the reaction of the lower Rhine region.

change in the seasonal pattern with respect to total runoff and groundwater recharge were computed. In comparison, an interaction of the soil profile with groundwater (= shallow groundwater table) had a much larger effect. Figure 4 shows that the general pattern of the seasonal dynamics (moist versus dry periods) is maintained for Northwest Germany, while the amplitude and therefore the seasonal variability of the water flows is considerably increased for groundwater recharge and evapotranspiration and total runoff (not shown). Only the seasonal distribution of the change in soil moisture shows smaller values for shallow groundwater tables which could be expected due to capillary rise of groundwater into the soil profile during dry periods.

The results presented for Northwest Germany show the same systematics compared to the simulation results of all other regions. Groundwater influence amplifies the seasonal dynamics of the simulated water flows such as total runoff, groundwater recharge and evapotranspiration while it has a compensational impact on the seasonal variability of state variables such as soil moisture. The ranking of the scenarios with respect to the intensity of their impact on hydrological fluxes and state variables remains unchanged: A1B scenario affects the hydrological system more intensively than scenario B1 does.

\section{Discussion}

The analysis of the impact of climate change on the hydrological regime of different regions within Germany reveals that the projected hydrological changes are strongly dependent on the projected regional climate change. Furthermore, the magnitude of projected climatic and hydrological change strongly depends on the compartments of the model chain used to simulate the climate change itself as well as the climate change impacts, because different global and regional 

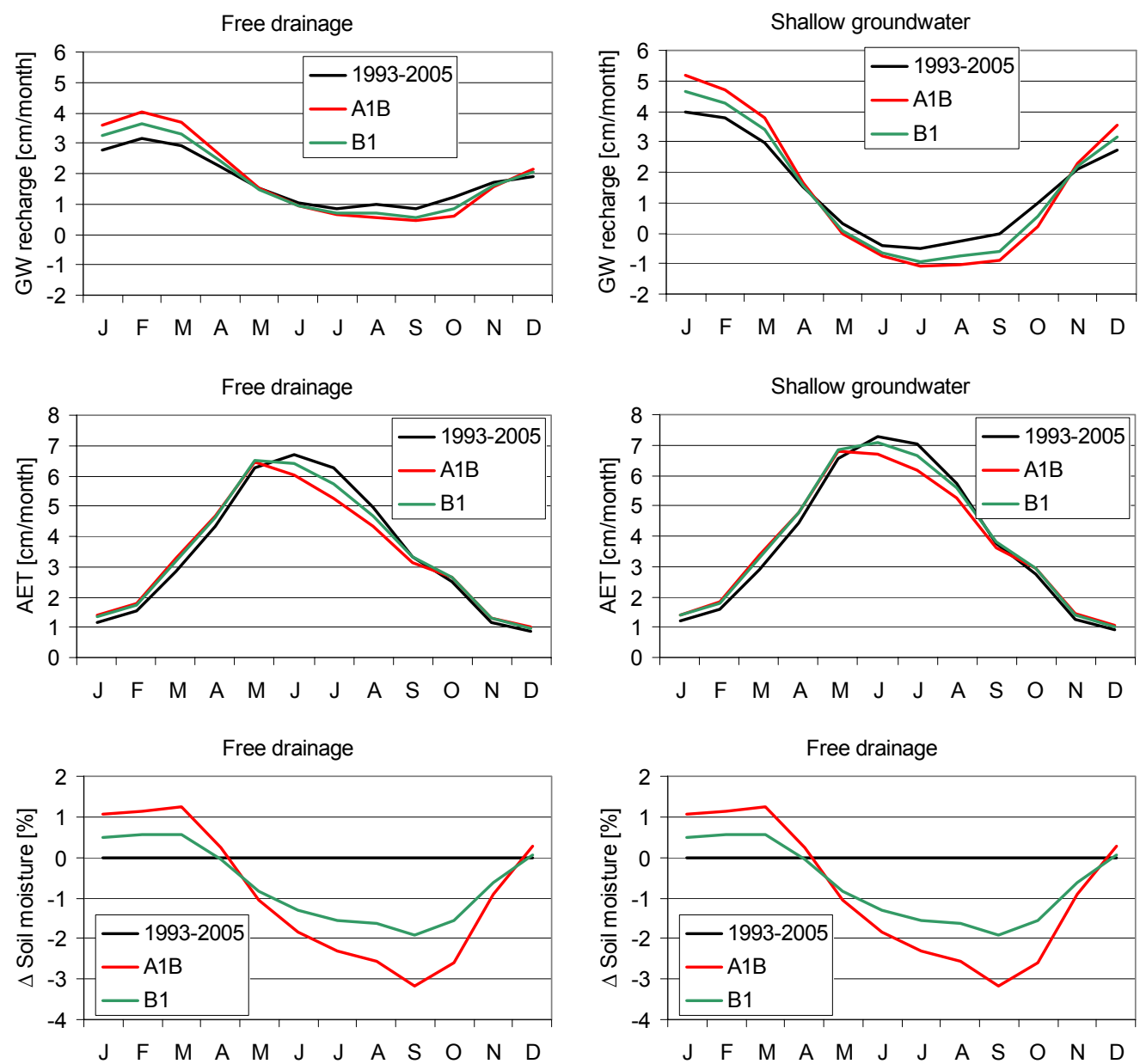

Fig. 4. Impact of climate change scenarios on the seasonal variation of simulated water flows depending on the lower boundary condition (groundwater influence versus free drainage) for Northwest Germany; AET = actual evapotranspiration; $\mathrm{GW}=$ groundwater; $\Delta=$ change.

climate models might result in different climate projections for the same scenario. Consequently, the suitability of the models (ECHAM5, WETTREG, SIMULAT) for the purpose of the study needs to be discussed.

At first the question arises on the robustness of the regional climate change signals between different global climate models. The IPCC initiative showed that the signal of temperature increase is projected very similar by the different models for central Europe (IPCC, 2007). Hence, the uncertainty attributed to the projection of temperature can be assumed to be small. With respect to precipitation, most of the global climate models agree at least on the direction of seasonal change in precipitation (IPCC, 2007). While all models, contributing to the regional climate projections, project an increase in winterly precipitation, most of the models project a summerly decrease in precipitation, as assumed in this study by applying the WETTREG scenarios. Admittedly the amount of change, projected by the different models varies remarkably, while the precipitation projections for
Germany at least differ less than they do for other parts of Europe. However, as shown by Bormann (2008) the impact of regional climate change on change in regional water balances is more important compared to differences in the catchment properties (e.g., land use, soil texture). Therefore this study is at least a good example to highlight the impact of different intensities of climate change, in this study represented by the different regions within Germany.

A second question is the degree of representativeness of the regional climate projections. Is the WETTREG model suitable to project regionally specific changes in seasonal variability of climate? Due to the fact that, in this study, the focus was to analyse the hydrological effects of different climatic changes in different regions, a validation of the WETTREG model for all regions was not realistic as part of the study. Nevertheless, UBA (2007) analysed the uncertainty of the WETTREG model over entire Germany and stated that differences between observations and model results are mostly below $0.5^{\circ} \mathrm{C}$ for temperature. With respect 
to seasonal precipitation, all deviations in summer and winter precipitation between model and observation were smaller than $10 \%$. Average deviations were $0.0 \%$ for annual values and between 0 and $1.5 \%$ for seasonal precipitation. Based on these values it can be stated that the uncertainty in climate model results in the control run was significantly smaller than the climate change rates resulting from the scenarios (change in temperature of +1.5 to $+2.5^{\circ} \mathrm{C}$; change in summer precipitation of -5 to $-50 \%$; change in winter precipitation of +10 to $+50 \%$ ). In addition, as mentioned above Bronstert et al. (2006) showed for Southern Germany that WETTREG was able to represent regionally different mean conditions as well as their seasonal variability. Therefore it can be assumed that WETTREG is suitable to project scenario specific changes in seasonal climate variability, required by this study to quantify possible change in future seasonal hydrological behaviour.

Finally, the question needs to be answered whether the physically based SVAT model SIMULAT is a suitable model for the purpose of this study. Is the sensitivity of SIMULAT to climate change realistic? Jiang et al. (2007) showed that the model specific sensitivity to climate change of 6 models applied to Chinese catchments differed significantly between different catchment models. They argued that different model structures of conceptual models can raise different model sensitivities to changes in climate although all different model structures could be well calibrated to present climate. The SIMULAT model applied in this study is a physically based model which does not need any calibration except for the parameters representing the baseflow recession module which was not used in this study. Without calibration, SIMULAT could be successfully validated in several studies for different climates (tropical and temperate), regions and spatial scales. Therefore it can be expected that the model shows a realistic and plausible sensitivity to climate change and is suitable in terms of the purpose of the study.

Summarising, the assumptions made for this study enabled to compose a scenario inventory which consists of regionally specific change rates. However, it has been demonstrated that climate change is the dominant influence on the change in seasonal hydrological behaviour of regions. Thus, assuming a reliable sensitivity of the hydrological model to climate change, the results of this study (= sensitivity to climate change) can be transferred to other regions whilst the assumed range of change in climate is representative for a specific region. The results therefore represent an inventory of typical hydrological climate change effects depending on the rates of change.

\section{Conclusions}

In this study two climate scenarios, which are provided by the statistical regional climate model WETTREG, are transformed into hydrological regimes using the physically based SVAT model SIMULAT. The simulation results suggest that future climate change will have a considerable impact on regional runoff regimes and hydrological regimes as well. The seasonality of most of the investigated regional hydrological regimes will amplify. Based on this scenario analysis it can be assumed that the seasonal variability of most hydrological processes, such as runoff generation, groundwater recharge and evapotranspiration, as well as state variables, such as soil moisture, will increase.

However, the results of this study are limited by the fact that only one regional climate model, based on the simulations of one global climate model, was used to drive one hydrological model to project the hydrological implications of climate change in different regions. To ensure the projected changes, additional (validated) climate and hydrological models should be applied in order to check model sensitivity to climate change.

Nevertheless, the major trends projected by the model chain used in this study go in the same direction for both scenarios and all investigated regions despite the regionally variable climate change projections. Therefore the direction of changes does not seem to be questionable any more. Only the intensity of change still needs to be determined with increased certainty. Hence, it seems to be obvious that an adaptation to future climate change (and therefore hydrological change) is required for water related issues such as water management as well as for ecological purposes. The magnitude of change will determine the suitability of adaptation measures. Therefore, future research should focus on both aspects: to reduce the uncertainty of climate projections and their implications on regional hydrological cycle, and to develop and reassess adaptation measures to altered hydrological conditions. The latter aspect is the central focus of the new EU-Interreg IVb project "Climate Proof Areas" exploring future water management scenarios for the North Sea region, focusing on the Wesermarsch in Northwest Germany.

Acknowledgements. The author thanks the organisers of the KielWorkshop on "Großskalige Modellierung in der Hydrologie" for the excellent organisation of the Workshop. The "German Weather Service (DWD)" and the "Umweltbundesamt" are gratefully acknowledged for providing observed climate data and climate scenarios. The referees are thanked for their helpful comments which improved the paper.

Edited by: B. Schmalz, K. Bieger, and N. Fohrer Reviewed by: P. Krause and another anonymous referee 


\section{References}

Aden, K. and Diekkrüger, B.: Modeling pesticide dynamics of four different sites using the model system SIMULAT, Agr. Water Manag., 44, 337-355, 2000.

Ad-hoc AG Boden: Bodenkundliche Kartieranleitung. 5. Aufl., Schweizerbart, 438 pp., 2005.

Belz, J. U., Brahmer, G., Buiteveld, H., Engel, H., Grabher, R., Hodel, H. P., Krahe, P., Lammersen, R., Larina, M., Mendel, H. G., Meuser, A., Muller, G., Plonka, B., Pfister, L., and van Vuuren, W.: Das Abflussregime des Rheins und seiner Nebenflüsse im 20. Jahrhundert, Analyse, Veränderungen, Trends, KHRReport, 1-22, 376 pp., 2007.

Bormann, H., Diekkrüger, B., and Renschler, C.: Regionalization concept for hydrological modelling on different scales using a physically based model: results and evaluation, Phys. Chem. Earth Pt. B, 24(7), 799-804, 1999.

Bormann, H.: Hochskalieren von prozessorientierten Wassertransportmodellen - Methoden und Grenzen, München, Germany, Herbert-Utz-Verlag, 176 pp., 2001.

Bormann, H., Giertz, S., and Diekkrüger, B.: Hydrological catchment models between process representation, data availability and applicability for water management - case study for Benin, IAHS-Publication, 295, 86-93, 2005.

Bormann, H.: Verfügbarkeit von Oberflächen und Grundwasser - Modellstudien. In: Kleeberg, H.-B. (Ed.): Klimawandel Was kann die Wasserwirtschaft tun?, Forum für Hydrologie und Wasserwirtschaft, 24 August, 53-71, 2008.

Bormann, H.: Zur Analyse der durch Klimawandel bedingten Veränderungen der Abflussregime an Pegelstationen ausgewählter Flüsse in Deutschland. Hydrologie und Wasserbewirtschaftung, in press, 2009.

Bronstert, A., Kolokotronis, V., Schwandt, D., and Straub, H.: Vergleich und hydrologische Wertung regionaler Klimaszenarien für Süddeutschland, Hydrologie und Wasserbewirtschaftung, 50(6), 270-287, 2006.

Diekkrüger, B. and Arning, M.: Simulation of water fluxes using different methods for estimating soil parameters, Ecol. Model., 81(1-3), 83-95, 1995.

Diekkrüger, B., Söndgerath, D., Kersebaum, K. C., and McVoy, C. W.: Validity of agroecosystem models - A comparison of results of different models applied to the same data set, Ecol. Model., 81(1-3), 3-29, 1995.

Feddes, R. A., Kowalik, P. J., and Zaradny, H.: Simulation of field water use and crop yield, Simulations Monograph, Pudoc, Wageningen, The Netherlands, 1978.

Fowler, H. J., Kilsby, C. G., and Stunell, J.: Modelling the impacts of projected future climate change on water resources in northwest England, Hydrol. Earth Syst. Sci., 11(3), 1115-1126, 2007.

Giertz, S., Diekkrüger, B., and Steup, G.: Physically-based modelling of hydrological processes in a tropical headwater catchment in Benin (West Africa) - process representation and multicriteria validation, Hydrol. Earth Syst. Sci., 10, 829-847, 2006, http://www.hydrol-earth-syst-sci.net/10/829/2006/.

IPCC: Climate Change 2007 - The Physical Science Basis. Contribution of Working Group I to the Fourth Assessment Report of the IPCC, Cambridge University Press, 2007.

Jiang, T., Chen, Y. D., Xu, C., Chen, X., Chen, X., and Singh, V. P.: Comparison of hydrological impacts of climate change simulated by six hydrological models in the Dongjiang Basin, South China,
J. Hydrol., 336, 316-333, 2007.

Kilsby, C. G., Tellier, S. S., Fowler, H. J., and Howels, T. R.: Hydrological impacts of climate change on the Tejo and Guadiana Rivers, Hydrol. Earth Syst. Sci., 11(3), 1175-1189, 2007.

Kuhn, M.: Untersuchungen zur Auswirkung der Variabilität von Bodeneigenschaften auf die Wasserflüsse - Feldversuch und Simulation. Landschaftsökologie und Umweltforschung 31, TU Braunschweig, Germany, 173 pp., 1998.

Rawls, W. J. and Brakensiek, D. L.: Prediction of soil water properties for hydrological modelling, in: Proceedings of the symposium watershed management in the eighties, edited by: Jones, E. and Ward, T. J., Denver, USA, 293-299, 1985.

Richter, O., Söndgerath, D., and Diekkrüger, B.: Sonderforschungsbereich 179, Wasser- und Stoffdynamik in Agrarökosystemen“, Abschlußbericht, Landschaftsökologie und Umweltforschung, Braunschweig, Germany, 24(1), 407 pp., 1996.

Ritchie, J. T.: A model for predicting evaporation from a row crop with incomplete cover, Water Resour. Res., 8(5), 1204-1213, 1972.

Schönwiese, C.-D.: Das Klima der jüngeren Vergangenheit, Physik in unserer Zeit, 30(3), 94-101, 1999.

Stephan, K.: Möglichkeiten der Aggregierung heterogener Eingangsdaten für eine prozessorientierte hydrologische Simulation der Wasserflüsse am Beispiel des Untersuchungsgebietes der Oberen Leine, Dissertation, Math.-Nat. Fak. Univ. Bonn, Germany, available under: http://hss.ulb.uni-bonn.de/ulb_bonn/diss_ online/math_nat_fak/2003/stephan_klaus/index.htm, (last access: 15 December 2008), 2003.

Smith, R. E. and Parlange, J.-Y.: A parameter-efficient hydrologic infiltration model, Water Resour. Res., 14(3), 533-538, 1978.

Thodsen, H.: The influence of climate change on stream flow in Danish rivers, J. Hydrol., 333, 226-238, 2007.

UBA: Neuentwicklung von regional hoch aufgelösten Wetterlagen für Deutschland und Bereitstellung regionaler Klimaszenarios auf der Basis von globalen Klimasimulationen mit dem Regionalisierungsmodell WETTREG auf der Basis von globalen Klimasimulationen mit ECHAM5/MPI-OM T63L31 2010 bis 2100 für die SRES-Szenarios B1, A1B und A2. Forschungsprojekt im Auftrag des Umweltbundesamtes FuEVorhaben Förderkennzeichen 20441 138: A. Spekat et al. (January 2007), 2007.

Wagener, T.: Can we model the hydrological impacts of environmental change?, Hydrol. Proc., 21, 3233-3236, 2007.

Wechsung, F., Hanspach, A., Hattermann, F., Werner, P. C., and Gerstengarbe, F.-W.: Klima- und Anthropogene Wirkungen auf den Niedrigwasserabfluss der mittleren Elbe: Konsequenzen für Unterhaltungsziele und Ausbaunutzen. Ed.: Bund für Umwelt und Naturschutz: World Wide Fund for Nature, Deutsche Umwelthilfe e.V. Potsdam Institute for Climate Impact Research, 48 pp., available under: http://www.glowa-elbe.de, (last access: 19 November 2008), 2006.

Wilby R. L., Whitehead, P. G., Wade, A. J., Butterfield, D., Davis, R. J., and Watts, G.: Integrated modelling of climate change impacts on water resources and quality in a lowland catchment: River Kennet, UK, J. Hydrol., 330, 204-220, 2006. 